\title{
English Language Teaching and Learning Issues in Batam Learners' Perception via Facebook Dialog Journal
}

\author{
Warno Edi \\ English Department \\ University of Riau Kepulauan \\ warnopyaar@yahoo.com
}

\begin{abstract}
The purpose of this research was to gather English as a second language (ESL) learners perceptions pertaining to their experience in learning English language in secondary schools, colleges and local universities. The research methodology incorporated dialog journal using facebook. Dialog journal is a written communication between a teacher and students or other writing partners, which provides a natural context for language development and a new channel of communication outside the classroom. The research incorporated facebook as it currently one of the most prominent online social networking sites among Indonesians. 46 respondents from public and private colleges and universities discussed various learning issues including impediment that they encountered during English lessons in secondary school, college and university: learners' views and comments on issues pertaining to local English language teaching and learning; and suggestions to improve the teaching and learning of English. The discussion revealed varying viewpoints such as difficulties and reasons that students faced in learning the four language skills i.e. speaking, listening, reading and writing; and the lack of confidence which hampered their language improvement. This research hopes to enlighten educators of arduous challenges that students faced learning the English language so that they may strive to improve and consolidate their teaching skills.
\end{abstract}

Key Words: Dialogue Response Journal; Language Proficiency; and Language Skills.

\section{INTRODUCTION}

According to Zou (2006) different researchers have their own understanding of what constitutes learning styles. Honigsfeld and Dunn (2006) define it as a biological and developmental set of personal characteristics that make the same instruction effective for some learners and ineffective for others. Students spend between 11-13 years (6 years in primary school and between 5-7 years in secondary school) learning English, but a portion of students are still not able to master the language upon completing secondary school. There are various factors that could have contributed to this failure- learner learning methods, motivation, perception, teachers' teaching methods and/or approach, syllabus and lesson plan, among others. Therefore, it is imperative to understand learners' view and experiences in 
learning a second language in order to identify the difficulties and impediments that they encounter in the classrooms. The objectives of this research are (1) To gather learners' experience and views pertaining to issues on English language learning problems in secondary school, college or university; (2) To gather learners' views on English language teaching and learning in secondary school, college and university. Teachers need to know and understand the impediment that learners' experience in learning the four skills vie, listening, speaking, reading and writing in order to prepare effective lessons and to guide learners in developing their language proficiency. Therefore, it is pertinent that learners need to be given the opportunity to express their views pertaining to their learning experience to ensure teaching and learning is effectively carried out in the classrooms. The research questions in this study are (1)What are the language learning problems did ESL learners' encounter in secondary school, college or university namely speaking, listening, reading, and writing; (2) What are ESL learners' views on the issues of English language teaching and learning? and (3) What are ESL learners' suggestions to enhance the teaching and learning of English?

\section{METHODS}

A qualitative method was used to conduct the research by utilizing the content analysis of journal entries written by 46 private and public college and university students. A purposive sampling was used to select the 46 respondents who were former students of a public secondary school in Kota Batam, Kepri. The respondents were first to fifth semester students from various courses, who scored between band 2 to band 5 (band 1- limited user and band 6- highly proficient user) in their Indonesian university English test.

\section{RESULTS}

By utilizing facebook, a closed- group was created to gather the 46 samples. Other facebook users who were not registered in the group were not able to read the respondents' comments nor post their views. The note feature on the facebook account was used as an alternative form of journal. It was a mean to ensure that all respondents contributed their opinions and suggestions pertaining to a question posted by the researcher. The respondents must write in proper English i.e. complete and grammatically correct sentences and they were 
not allowed to use abbreviations such as LOL (Laugh Out Loud), BTW (By the Way), IMHO ( In My Humble Opinion), among others. In the dialogue journals, the researcher posted three questions on the group's wall message and the respondents wrote their views and suggestion on their personal note. The researcher responded and prompted questions when there were ambiguous responses. Other respondents were also allowed to contribute their views and suggestions on their group members' journal entries. This eventually evolved into a dialogue. The journal entries were analyzed using content analysis and categorized according to the learners' problems in learning the four language skills vise, speaking, listening, reading, and writing; learners' classrooms observations; and learner's suggestions to teachers and other learners on the teaching and learning of English. Frequency count was used to score the responses.

\section{DISCUSSION}

This section discusses the findings of the research namely I) the respondents' views pertaining to the problems they experienced in learning the four language skills; ii) respondents' suggestions for teachers to enhance their teaching effectiveness and for other learners to improve their language skills based on the respondents' personal approaches. This section provides the finding on the respondents' views pertaining to language learning impediments that they experienced in learning the four skills namely speaking, listening, reading, and writing.

\section{Table 1}

Speaking Problems and Reasons among ESL Learners

\begin{tabular}{|l|l|l|}
\hline \multicolumn{1}{|c|}{ Total Respondents } & \multicolumn{1}{|c|}{ Problems } & \multicolumn{1}{c|}{ reasons } \\
\hline 18 respondents & $\begin{array}{l}\text { - Hestitated to speak English with their } \\
\text { teachers and friends in and/ or outside } \\
\text { the classroom }\end{array}$ & $\begin{array}{l}\text { - Worried about making grammatical } \\
\text { mistakes. } \\
\text { - Felt embarrassed of their low language } \\
\text { proficiency. } \\
\text { Received negative physical response } \\
\text { (smirk) }\end{array}$ \\
\hline 16 respondents & $\begin{array}{l}\text { - Felt self- conscious about their } \\
\text { speaking profiency. }\end{array}$ & $\begin{array}{l}\text { Negative preliminary presumptions } \\
\text { about proficient speakers' views } \\
\text { toward them e.g. not intelligent, } \\
\text { incompetent, dull }\end{array}$ \\
\hline
\end{tabular}




\begin{tabular}{|l|l|l|}
\hline 31 respondents & $\begin{array}{l}\bullet \text { Difficulty in speaking fluently. } \\
\bullet \text { Mixing other languages with English in } \\
\text { their conversation }\end{array}$ & $\begin{array}{l}\bullet \text { Unfamiliar with certain English } \\
\text { vocabulary. }\end{array}$ \\
\hline $\begin{array}{l}\text { 6 respondents (band 5 } \\
\text { students) }\end{array}$ & $\bullet$ No difficulty in speaking. & \\
\hline
\end{tabular}

In Table 1, 18 respondents stated that they hesitated to speak English with their teachers and friends in or outside the classroom because they worried about making grammatical mistakes and felt embarrassed of their low language proficiency. This is due to the negative physical response, such as a smirk, that they received from other more proficient speakers when learners spoke incorrectly. Meanwhile, 16 respondents stated they felt self- conscious about their speaking proficiency because they have negative preliminary presumptions about proficient speakers' view towards them as being slow learners, incompetent and dull, among others. As a result, they were not fully involved in classroom activities even though they were constantly encouraged to speak freely by their teachers without being judgmental. This can cause detrimental effects on learners' motivation and confidence. The majority of Indonesian' students are bilingual who speak Bahasa Indonesia as the national language, and English, the second language. Both languages are compulsory subjects in the Indonesian education syllabus. Due to these circumstances, 31 respondents experienced difficult speaking fluently due to unfamiliarity with some English vocabulary. This caused the respondents to incorporate other local language and dialects with English to ensure their meanings, intentions or thoughts are unambiguous. Unfortunately, the attempt hindered the respondents' speaking fluency. An example given by a respondent is as follow:

'I think you should try 'meyakinkan' (to convince) your parents to 'beri kebenaran' (give permission) for you to join us on the trip."

As a result, the respondents usually experience moderate anxiety and are reluctant to speak in English for fear of being judged negatively. 
Table 2

Listening Problems, Reasons and Effects among ESL Learners

\begin{tabular}{|c|c|c|c|}
\hline Total Respondents & Problems & Reason & Effects \\
\hline 15 respondents & $\begin{array}{l}\text { - Unable to the } \\
\text { fully understand } \\
\text { their teachers } \\
\text { and lecturers }\end{array}$ & 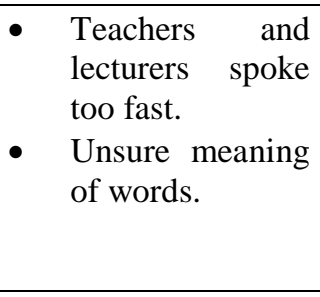 & 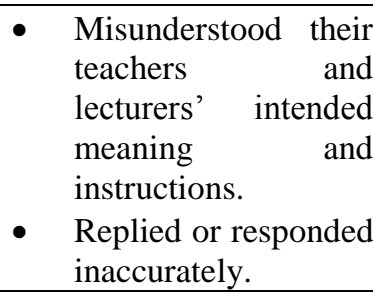 \\
\hline 11 respondents & $\begin{array}{l}\text { - Unable to keep } \\
\text { up with parts of } \\
\text { a conversation or } \\
\text { discussion with } \\
\text { their classmates } \\
\text { and course mates }\end{array}$ & $\begin{array}{l}\text { - Unfamiliar with } \\
\text { the topics of } \\
\text { conversation or } \\
\text { discussion. } \\
\text { - Speakers spoke } \\
\text { too fast } \\
\end{array}$ & $\begin{array}{l}\text { Asked speakers for } \\
\text { clarification. }\end{array}$ \\
\hline 9 respondents & $\begin{array}{l}\text { Unfamiliar with } \\
\text { meanings of } \\
\text { certain words } \\
\text { during } \\
\text { conversation }\end{array}$ & & 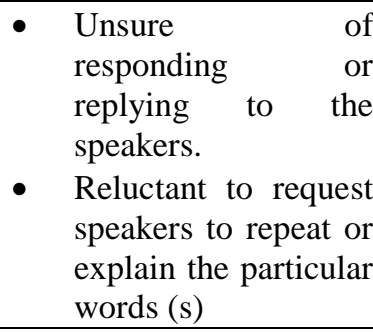 \\
\hline $\begin{array}{l}10 \quad \text { respondents } \\
\text { (Band } 4 \text { and } 5 \text { ) }\end{array}$ & $\begin{array}{ll}\text { - } & \text { Almost } \\
\text { problem } \\
\text { listening } \\
\end{array}$ & & \\
\hline
\end{tabular}

Table 2 shows that 15 respondents were unable to understand their teachers and lecturers because they spoke too fast during conversations, when giving instructions or explaining a topic. The second reason was due to uncertainty of meaning of words. As result, the learners misunderstood their teacher's intended meaning of the conversation and instruction, thus replying or responding incorrectly. Meanwhile, 11 other respondents wrote that they were unable to keep up with certain parts of a conversation or discussion in the classroom because they were either not familiar with the topic or the speakers spoke too fast. It resulted in them asking the speakers for clarification or temporarily putting aside the ambiguous topic and seeking clarification at a later period. In addition, nine respondents related their experience about being unsure of meanings of certains words during a conversation which made them reluctant to respond or reply to the speakers. They feared the speakers would view them negatively as being incompetent in the language. 10 respondents who were satisfactory and proficient users (Band 4 and 5) had almost no problem in listening. 


\section{Table 3}

Reading Problems, Reasons and Effect among ESL Learners

\begin{tabular}{|c|c|c|c|}
\hline Total Respondents & Problems & Reason & Effects \\
\hline 25 respondents & $\begin{array}{ll}\text { - Unable to fully } \\
\text { comprehend } \\
\text { passages } \\
\text { articles. }\end{array}$ & $\begin{array}{ll} & \text { Encountered many } \\
\text { unfamiliar words }\end{array}$ & 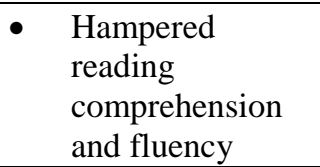 \\
\hline 21 respondents & $\begin{array}{lrr}\text { Required } & \text { longer } \\
\text { duration to } & \text { read } \\
\text { passages } & \text { and } \\
\text { articles } & \end{array}$ & $\begin{array}{ll} & \text { Encountered many } \\
\text { unfamiliar words }\end{array}$ & $\begin{array}{ll}\text { - } & \text { Constantly } \\
\text { referred } & \text { to } \\
\text { English } & \text { and } \\
\text { bilingual } & \\
\text { dictionaries } & \end{array}$ \\
\hline $\begin{array}{l}6 \text { respondents (Band } 5 \\
\text { students }\end{array}$ & $\begin{array}{ll}\text { - } & \text { Occasionally } \\
\text { encountered } \\
\text { unfamiliar words }\end{array}$ & - $\quad$ Not mentioned & 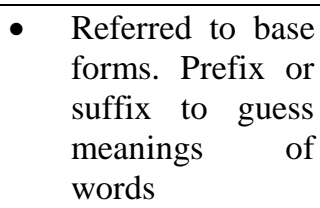 \\
\hline
\end{tabular}

Based on Table 3, 25 respondents claimed they experienced problem comprehending passages and articles while 21 respondents required longer duration to complete the reading materials. The aforementioned 46 respondents gave the same reason to their impediment whereby they encountered many unfamiliar words which hampered their reading comprehension and fluency. Besides, they had to constantly refer to English and bilingual dictionaries to look up for the meaning of the unfamiliar words. In these situations, learners need to be taught and reminded to skim and scan reading passages especially when a limited time frame is given e.g. during reading exercises or test. Meanwhile, six respondents who scored Band 5 said that they occasionally encountered unfamiliar words which hampered their reading comprehension but were able to make sense of the passages by referring to the base forms, prefix of suffix to guess the meanings of the words.

Table 4

Writing Problems and Reason among ESL Learners

\begin{tabular}{|l|ll|l|}
\hline \multicolumn{1}{|c|}{ Total Respondents } & Problem & \multicolumn{1}{c|}{ Reasons } \\
\hline 32 respondents & $\begin{array}{l}\text { Required longer period } \\
\text { to write an essay }\end{array}$ & $\begin{array}{l}\text { Pre- writing stage: } \\
\text { Difficulty procuring } \\
\text { ideas to write essay } \\
\text { outlines. }\end{array}$ \\
& $\begin{array}{l}\text { Not familiar with the } \\
\text { topics. }\end{array}$ & $\begin{array}{l}\text { Writing stage: } \\
\text { Mentally construct } \\
\text { sentences in mother } \\
\text { tongue before } \\
\text { translating into English. }\end{array}$ \\
& \\
& \\
\end{tabular}




\begin{tabular}{|c|c|c|}
\hline & & $\begin{array}{l}\text { - Constantly referring to } \\
\text { English and bilingual } \\
\text { dictionaries, and online } \\
\text { translator } \\
\text { Revising stage: } \\
\text { - To ensure sentences } \\
\text { were grammatically } \\
\text { correct and } \\
\text { comprehensible } \\
\text { To ensure ideas, } \\
\text { sentences and } \\
\text { paragraphs were } \\
\text { arranged coherently and } \\
\text { cohesively. }\end{array}$ \\
\hline 11 respondents & $\begin{array}{l}\text { - Difficulty in writing } \\
\text { academic essays. }\end{array}$ & 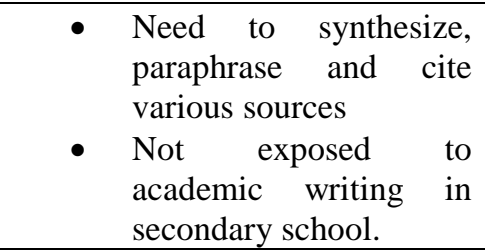 \\
\hline
\end{tabular}

Writing is one of the most difficult skills to master in learning a language, the findings in table 4 showed that 32 respondents stated they required longer period to write an essay as they experience difficulty procuring ideas to plan their essay outlines in the pre-writing stage. Finally in the revising stage the respondents had to make sure that their sentences and paragraphs were arranged coherently and cohesively. The later essay requires learners to synthesise, paraphrase and cite various sources, which the respondents were not familiar with because they were not exposed to academic writing in secondary. Thus, it was difficult for them to master the writing style within a short semester.

This section provides the finding on the respondents' views and comments pertaining to two issues on English language teaching and learning learning namely their teachers and lecturers' teaching approach in school, college and university, and students' negative perceptions towards learning English.

Table 5

ESL Learning's Views on Teachers' Teaching Approach

\begin{tabular}{|c|rl|}
\hline Total Respondents & \multicolumn{1}{c|}{ views } \\
\hline $\mathbf{2 8}$ respondents & $\bullet$ & $\begin{array}{l}\text { Disagreed with teachers who were adamant about } \\
\text { speaking only English in the classroom }\end{array}$ \\
\hline $\mathbf{2 1}$ respondents & $\bullet$ & Teachers and lecturers' lessons were non-interactive \\
\hline
\end{tabular}


Based on Table 5. 28 respondents said they disagreed with teachers who adamant about speaking only English in the classroom and also imposing similar partice upon the students. They opined that is was necassary for teachers to explain certain procedures and meaning in the students' mother-tongues so that they can fully comprehend the teachers' explanation. The respondents commended the teachers' intentions to ensure their students mastered the English language but they also needed to practice more flexibility and leniency in accommodating to the students' language limitations. By doing so, both teachers and students will be ableto provide and obtain effective and meaningful language learning experience, respectively. Meanwhile, 21 respondents thought some of their teachers and lecturers' lessons were non-interactive i.e. The lessons were textbook-based, lacked pair or group discussions and presentations.

\section{Table 6}

ESLLearners' Reasons for Students' Negative Perceptions toward Learning English

\begin{tabular}{|c|c|}
\hline Total Respondents & Views \\
\hline 25 respondents & $\begin{array}{l}\text { - Passive learners viewed English as just another subject to } \\
\text { pass. Has no necessity and practicalilty in their future }\end{array}$ \\
\hline 21 respondents & $\begin{array}{l}\text { - Passive learners have no intention to futher their studies } \\
\text { upon completing secondary school } \\
\text { - } \quad \text { Passive learners intend to seek employment }\end{array}$ \\
\hline
\end{tabular}

According to the respondents who were proactive in learning the English language as shown on Table 6, 25 respondents mentioned that their former secondary schoolmates who were passive learners viewed English as just a subject to pass and did not see the necessity and practicality of it in their future careers. This was supported by 21 respondents who said that low academic achievers did not intend to further their studies and planned to seek employment, usually as odd job workers, upon completing secondary school. Some of the reasons given were reasonable such as students were not academically-inclined, they came from low-income families whose parents could not afford to provide financial support for them to further their studies, and some students had many siblings which required them to work and provide financial assistance to support their parents and families, among the reasons. 
This section provides the findings of the respondents' suggestions for teachers and lecturers to improve their teaching approach in the classroom: and for students to improve their language skills based on the respondents' experience and personal approaches.

Table 7

ESL Learners' Suggestions to Improve Teacher's Teaching Approach

\begin{tabular}{|c|c|}
\hline TOTAL RESPONDENTS & SUGGESTIONS \\
\hline 5 respondents & - $\quad$ Be more patient in guiding and teaching students \\
\hline 28 respondents & $\begin{array}{l}\text { - Teachers and lecturers should be more creative in their } \\
\text { lesson and not rely only on textbooks }\end{array}$ \\
\hline 39 respondents & $\begin{array}{l}\text { - Teachers and lecturers should use other mother- tongues } \\
\text { to explain meanings of unfamiliar words }\end{array}$ \\
\hline 22 respondents & $\begin{array}{l}\text { - Teachers and lecturers should introduce new vocabulary } \\
\text { during lessons }\end{array}$ \\
\hline
\end{tabular}

In table 7, five respondents suggested that should be more patient in guiding and teaching especially the lower and average proficiency students. This will ensure students are more motivated and responsive towards the teachers and lesson. Meanwhile, 28 respondents preferred if teachers and lecturers incorporated more creative teaching approaches in their lessons such as using interactive online programmes and videos instead of the conventional 'chalk-and-talk', PowerPoint and textbook-based lessons. 39 respondents opined that educators should use their students' mother-tongues, depending on the educators' command of the language, to explain meanings of unifamiliars words. Finally, 22 respondents suggested that teachers should introduce new word during lessons as a mean to guide students to comprehend and use vocabulary correctly in proper contexts. In the Indonesian Curriculum Specifications for primary and secondary schools, it contains a word list which consists of high frequency words commonly used in the English language which learners are also the words that learners will use when going about their writing task. Teachers are encouraged to add to the word list according to the proficiency of their learners as well as when teaching a particular topic (Indonesian Curriculum, 2013). 


\section{Table 8}

ESL Learner's Suggestions to Improve Classroom Assignments and Activities

\begin{tabular}{|l|cl|}
\hline \multicolumn{1}{|c|}{ Total respondents } & \multicolumn{1}{c|}{ Suggestions } \\
\hline $\begin{array}{l}\text { 6 respondents (band 5 } \\
\text { students) }\end{array}$ & $\bullet$ & $\begin{array}{l}\text { More extensive, interactive and comprehensive individul or group } \\
\text { assignments and presentations }\end{array}$ \\
\hline $\mathbf{1 8}$ respondents & $\bullet \begin{array}{l}\text { Teachers and lecturers should incorporate games in a fun and interactive } \\
\text { way }\end{array}$ \\
\hline
\end{tabular}

Six respondents in Table 8 suggested that lecturers should plan more extensive, Interactive and comprehensive individual or group assignment and presentations which will be worthwhile and practical for them to be utilized in other courses, in addition to that. Lecturers should ensure that the presentations are conducted in a serious and formal environment, similar to a conference, in order to expose students to a simulated conference. Besides, it is also to ensure student invest more effort in completing their assignments and delivering excellent presentation. Secondly, 18 respondents viewed that games are effective methods to assist students in language learning as students are able to learn the language in context through a fun interactive way. The respondents who described their favorite English lessons in secondary school, college and university have similarly noted the use of games which made the lessons lively and memorable. On top of that, games gave opportunities to every student to shine especially shy learners who eventually became more outspoken and confident.

In the dialogues response journal, the respondents offered their advice and suggestions on ways to improve language development and proficiency based $\mathrm{n}$ their personal experience which were effective in helping them become better learners.

Table 9

ESL Learners' Suggestions to Improve Speaking and Listening Skills

\begin{tabular}{|l|rl|}
\hline Total Respondents & \multicolumn{1}{c|}{ Suggestions } \\
\hline & $\bullet$ & Converse with friends who have good command of English or \\
& & with English native speakers via Skype, Yahoo Messenger. \\
& 26 respondents & Watch English movies and documentaries. \\
& - & $\begin{array}{l}\text { Practice speaking in front of a small audience before a } \\
\text { presentation. }\end{array}$ \\
& & $\begin{array}{l}\text { Consistently practice speaking English with teachers, lecturers and } \\
\text { friends. }\end{array}$ \\
\hline
\end{tabular}


Based on Table 9, one of the 26 respondents stated that watching English movies and documentaries such as The National Geographic and Discoveryhelped him in his pronunciation, sentence structure construction, usage of word in contexts and vocabulary range development. Another respondents suggested watching English movies without foreign subtitles as this will force learners to focus on the spoken word. To improve one's speaking skill, three respondents suggested that learned should converse with friends, who have good command of English, and English native speakers via Skype, Yahoo Massenger or other forms of internet voice services. The continuing rapid advancement of information technology and multimedia has turned the world into a borderless continent especially with notable ubiquitous social networking sites such as Facebook, My Space and Tweeter. Six respondents suggested that local English teachers should contact overseas native English teachers to form and educational network which allows students from both countries and/or continent to socialize and help local learners to improve their communication skills.

It is a norm to feel nervous before a presentation for both proficient and less proficient speakers. Ten respondents said these worries can be reducing by practicing before a presentation in front of a small audience whom the speakers is comfortable with. Preliminary feedbacks and comments from peers will help speakers improve their presentation skills and boost their confidence. Once respondent of this research expressed his satisfaction participating in oratory presentations and competitions which helped to build his confidence and develop his speaking skill.

"My experience participating in oratory presentation and competitions such as public speaking and debates have helped elevate my confident and honed my speaking skill. Even though I never won, the experiences have been priceless.(sic)", 


\section{Table 10}

ESL Learners' Suggestions to Improve Writing Skill

\begin{tabular}{|l|l|l|}
\hline Total Respondents & \multicolumn{1}{|c|}{ SUGGESTIONS } & Benefits \\
\hline 18 respondents & $\bullet \quad \begin{array}{l}\text { Pratice writing daily. Be more patient in } \\
\text { guiding and teaching studentd }\end{array}$ & $\begin{array}{l}\text { Train students to put } \\
\text { thoughts in the words. } \\
\text { Train students to use } \\
\text { effective forms of } \\
\text { expression and suitable } \\
\text { choices of works }\end{array}$ \\
& $\begin{array}{l}\text { Learn new vocabulary and } \\
\text { synonyms through } \\
\text { dictionary and thesaurus }\end{array}$ \\
\hline
\end{tabular}

In table 10, 18 respondents agreed that practice writing daily helped to improve their writing skills as it trained them to put their thought into words in addition to using effective forms of expressions and suitable choices of words. Writing practice also helped the ESL learners learn new vocabulary and synonyms via English and Bilingual dictionaries, Thesaurus and reading newspapers, magazines and book.

\section{Table 11}

ESL Learners' Suggestions to Improve Reading Skill

\begin{tabular}{|c|c|c|}
\hline TOTAL RESPONDENTS & SUGGESTIONS & BENEFIT \\
\hline 13 RESPONDENTS & $\begin{array}{l}\text { READ ENGLISH news } \\
\text { reports and articles, story } \\
\text { books and magazine }\end{array}$ & 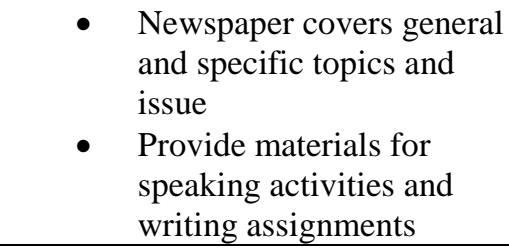 \\
\hline
\end{tabular}

13 respondents suggested and acceded by others, that reading newspaper reports and articles help to improve their reading skill addition to improving their speaking and writing skills, grammar proficiency, and expanding their vocabulary range as specific topics and issues such as education, environment, health, social issues, science and technology which are suitable for students to improve their vocabulary and applying them in speaking and writing. The respondents stated that they used these materials in their individual and/or speaking activities and writing assignments. 


\section{CONCLUSION AND SUGGESTIONS}

Learners' perceptions towards the teaching and learning of English should be then and reviewed seriously as it is a two-way process involving teachers and learners. Meanwhile, teachers should take the initiative to ensure their teaching plans are effective while students' learning styles and preferences. An empathic teacher can motivate reluctant students to explore their maximum potential through consistent encouragement and self-assurance. Besides, average and low proficiency until they are able to achieve their maximum ability. In the end, the results will be an equal achievement and success for both educators and learners.

\section{REFERENCES}

Second Language education”. Foreign Language Annals. Vol . 28. No. 1, pp 2131.

Honigsfeld, A., \& Dunn, R (2006), "Learning Style Characteristics of Adult Learners", The Delta Kappa Gemma Bulletin, Vol. 72, Issue 2, pp. 14- 31.

Indonesian Curriculum Spesification, (2013). “ English Language Curriculum Specifications”, Indonesian Ministry of Education. Jakarta.

Research and Practical Considered for Teaching in the Multicultural Tertiary ES1/EFL Classroom”, System, Vol. 20, Issue 4, pp 439456.

International Journal of Applied Linguistics, Vol 1, Issue 2, pp. 120. 